\title{
An Overview of the Development Electronic Wallet in Encouraging Economic Growth in the Indonesian Territory
}

\author{
Andres Dharma Nurhalim \\ Sekolah Tinggi Ilmu Ekonomi Wiyatamandala
}

\begin{abstract}
This article aims to discuss the problem of a electronic wallet capable of driving economic growth in the territory of Indonesia for businesses and the public. The analytical method used in conducting this research is to use one literature with another literature as a basis for arguing. With the development of digital wallet, it is hoped that it can accelerate economic growth and financial inclusion in Indonesia towards Indonesia with the inclusion of digital technology and is also expected to be able to reduce geographical barriers that can later be eliminated with digital capabilities. So that everyone can easily transaction through an electronic wallet.
\end{abstract}

Keywords: Electronic Wallet, Modern Financial, Financial Transaction 


\section{INTRODUCTION}

In the current era of globalization, Indonesian people are continuously encouraged to follow technological developments. One of them is electronic payment through e-wallet or electronic wallet. Various kinds of tempting facilities and benefits provided by electronic wallet developers to the people who cannot be separated from technological developments provide very rapid changes, such as the use of the internet which has become an important part of human life and the business world. The rapid development of technology has an impact on life for humans, with the increasing number of technological changes, this of course brings people to be able to facilitate activities in meeting all their needs. One way to utilize this technology is electronic wallet or in other words e-wallet. Electronic Wallet or e-wallet according to article 1 number 7 of Bank Indonesia Regulation Number 18/40 / PBI / 20162016 concerning the Implementation of Payment Transaction Processing ("PBI / 18/2016") is an electronic service for storing payment instrument data including payment instruments by using cards and / or electronic money, which can also hold funds, to make payments. Payments using electronic wallet in general at this time are more often used, among others, for online shopping, online transportation payments (Go-Jek, Grab), buying credit, paying toll booths, paying for parking to buying food both in stalls or in stores. From such an explanation so that it is clear that with the e-wallet, the payment process will be more integrated and can minimize the occurrence of problems. The sustainability of the electronic wallet can be seen in the table which shows the growth of non-cash payment transactions in Indonesia from January to June 2019, among others as follows:

Table 1 the growth number of non-cash payment transactions

\begin{tabular}{clccccc}
\multirow{2}{*}{ Period } & \multicolumn{5}{c}{2019} \\
& \multicolumn{1}{c}{ January } & February & March & April & May & June \\
Volume & $274,687,548$ & $294,101,832$ & $423,743,628$ & $451,650,065$ & $422,602,216$ & $393,695,970$ \\
Nominal & $5,817,363$ & $5,970,262$ & $8,956,978$ & $10,671,171$ & $12,815,686$ & $11,874,500$ \\
\hline
\end{tabular}

Volume in transaction units

Nominal in million

Source: www.bi.go.id

Based on the above table, it shows that from 2019 in January to March there has been an increase, while for April to June it has decreased dramatically by an average of around $7 \%$. The development of electronic wallet has become an interesting topic to be discussed over time as the development of advancing information technology is inseparable with the speed of the internet connection for the business world and human activities. The easier payment system support, the electronic transactions or electronic wallet activities will later develop. From this phenomenon, the banking industry is conventionally said to be displaced by the presence of financial technology (fintech) which will sooner or later push Indonesia to become a cashless society. Changes in payment transactions are not only felt by consumers, but businesses also feel this and move quickly by holding digital payment instruments and payment methods from several financial institutions. With these changes, businesses must be demanded to move quickly by following the times with digital payment methods to make it easier for 
them to transact with buyers. In addition, this also helped them in developing their business in increasingly fierce business competition. The increase in transaction activities using electronic wallet will have an impact on the increasing economic value added of the Indonesian region. The rapid development of technology has an impact on human life, with the increasing number of technological changes this can facilitate the activities in meeting all human needs. With the development of electronic wallet, it is hoped that it can accelerate economic growth and financial inclusion in Indonesia towards Indonesia with the inclusion of digital technology and is also expected to be able to reduce geographical obstacles that can later be eliminated with digital capabilities. So that everyone can transact easily through electronic wallet. Based on the background of the problem above, the problem formulation in this study is as follows:

1. Analyzing the impact of the development of electronic wallet for the business world and society.

2. Identifying the extent to which electronic wallets encourage regional economic growth in Indonesia.

\section{LITERATURE REVIEW}

According to Pachpande \& Kamble (2018) said that electronic wallet is a form of prepaid account to save money, which can be used to make transactions in the future. In general, the main transactions through e-wallet are payments, both for offline and online transactions. However, there are other features such as money transfers and cash withdrawals, which are present in several e-wallet providers. According to BCC Research (2019) said the value of the wallet in a mobile phone and payment technology market is estimated at USD 27.9 billion in 2017 globally and it is likely that for the next year this market will continue to develop rapidly in the future. According to Jain and Singla (2017) said that electronic wallet has three categories available in the market, namely: closed closed loop, semi closed loop and open loop electronic wallet. Closed loop electronic wallet is an e-wallet that allows customers to make payments only for goods and services from the issuing shop, without the features of money transfer and cash withdrawal. Semi closed loop electronic wallet is an e-wallet that allows customers to pay at participating merchants, without the features of money transfer and cash withdrawal; and finally, the open loop electronic wallet is an e-wallet, which allows customers to make payments for their purchases, make money transfers and cash withdrawals. But in reality, in Indonesia, only two categories are recognized, open loop e-wallet and closed loop, whereas semi closed loop e-wallet is categorized in open loop e-wallet. The process for gaining access to e-wallet is generally the same as that of many providers. First-time users need to register through the e-wallet mobile application that is downloaded either on the PlayStore or App store, provides the necessary information, and adds a balance before using it to make transactions. Users can add to their e-wallet balance through their bank account or through physical sales that participate with e-wallet providers. Payment methods for online transactions are also similar, namely through online platforms. According to (Shin, Jung, \& Chang: 2012) there are also methods used by providers to process offline payments, one of which uses (QR Code) or fast response code. QR Code is a matrix barcode, which contains information such as URLs, text, and other data designed to be readable by smartphones. 
In this case, the user can only scan the QR code to make payment. According to a report from Capgemini \& BNP Paribas (2018), a QR code based application is a key factor for e-wallet adoption in Asia, because it is easy, convenient, inexpensive, and does not require electricity, which makes it more convenient for areas with electricity supply that cannot be reliable. As mentioned earlier, the e-wallet industry will grow exponentially and is estimated to be worth USD 138.4 billion in 2023 (BCC Research, 2019). Of course this can provide valuable benefits when using e-wallets. Upadhayaya (2012) said that besides the benefits when using e-wallet such as making it easy to send and receive payments, convenience in entering money into the user's e-wallet account, being able to manage the account using a cell phone, etc. In addition, lower transaction costs and promotional offers are also the main benefits, which attract e-wallet usage. Electronic Wallet or electronic wallet according to Article 1 number 7 of Bank Indonesia Regulation Number 18/40 / PBI / 20162016 concerning the implementation of payment transaction processing ("PBI / 18/2016") is an electronic service for storing payment instrument data including payment instruments with use cards or electronic money that can also hold funds to make payments. In conducting electronic wallet organizers, it is divided into two types, namely banks and institutions other than banks. The institution other than the bank in question is a limited liability company where the obligation to obtain a permit as referred to in Article 4 paragraph (1) applies to banks or institutions other than banks as referred to in Article 7 paragraph (1) holding an electronic wallet with active users reaching or planned to be reaching at least 300,000 (three hundred thousand) users. There are a number of things that need to be considered in conducting electronic wallet organizers as referred to in Article 7 which must meet the eligibility aspects as providers of payment system services which include:
a. Legal and Company Profile;
b. Law;
c. Operational readiness;
d. System security and reliability;
e. Business worthed;
f. Adequacy of risk management; and
g. Consumer protection

In conducting electronic wallet organizers, both banks and non-bank institutions that will organize electronic wallets that can be used to store payment instrument data and hold funds, are required to:

a) Ensure the use of funds in electronic wallet is only for payment purposes;

b) Comply with Bank Indonesia regulations regarding the limits on the value of funds that can be accommodated in an electronic wallet;

c) Ensure that funds owned by users are available and can be used when making transactions;

d) Placing all funds stored in electronic wallet in the form of safe and liquid assets to ensure the availability of funds.

e) Ensuring that the use of funds is only to fulfill the interests of payment transactions by electronic wallet users; and 
f) Implement anti-money laundering and prevent terrorism funding programs in accordance with statutory provisions

\section{RESEARCH METHODS}

The research method used by the author in this case uses the study of literature by linking one literature with another literature as a basis for arguing, and for a deeper review, in conducting this research the author is supported by several interviews with business people and communities with electronic wallet, namely food vendors and consumers who have bought goods both online and offline. In developing the research, it is also supported by data from survey institutions which are published in the mass media as well as data from institutions related to the discussion in this paper about electronic wallet that encourages economic growth in the region in Indonesia.

\section{RESEARCH RESULTS AND DISCUSSION}

Electronic wallet is a concept that can be described as a vehicle for payment transactions to store payment instrument data, among others, as a means of payment using cards and / or electronic money, which can also hold funds, to make payments. Based on mass media sources katadata.co.id until the end of May 2019 there were 37 operators in Indonesia, of which the most were published by fintech companies. The most popular electronic wallets in 2018 include the following:

Figure 1 electronic wallet competition in Indonesia

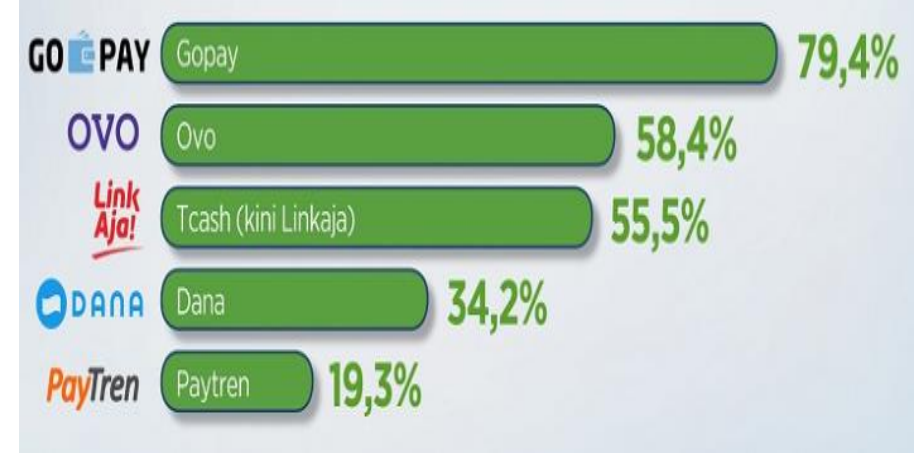

Source:katadata.co.id

Electronic wallet in Indonesia has a very good impact on businesses, as well as the general public. These impacts will certainly drive regional economic growth faster, safer and more comfortable than conventional transactions that occur in general. The advantages of using electronic wallet as the main payment tool according to Hadijah (2018) include:

a) Ease

By using an electronic wallet, users do not need to carry a thick wallet full of cash, debit or credit cards, or queue to make cash withdrawals at ATMs. Electronic wallet is much safer and easier to carry while traveling. In an emergency using an electronic wallet can make it easier for users when they have to pay online shopping but can not pay directly because they are unable to, users can use the electronic wallet service

b) Promotion

Various promotions presented by digital payment services will benefit users. Promotions such as cashback or discounts become one of the things that attract users to use the service. 
c) Transaction History

All digital payment services when making an expense transaction will later present the transaction history in their application.

d) Budget Discipline

The transaction history found in the electronic wallet application makes it easy for users to set a monthly budget for the following month. users can analyze spending in a month, then apply the results of the analysis to next month's budgeting. The budgeting will be able to create discipline in finance. users can set limits on each transaction that will be done.

e) Lower risk

Users can block electronic wallet through an account that is connected on a mobile device. That way, the money in the electronic wallet might not be used anymore.

f) Implied benefits

Users when making payment transactions can pay the right amount without worrying about no change from the business owner.

Electronic wallet is generally server based, in using the electronic wallet the user needs a device such as a computer, tablet or smart phone. If you want to make transactions with an electronic wallet, such as money transfers or payments, then the gadget needs to be connected to the issuing server via the internet network where the internet is one of the active communication media for 24 hours so that when people want to make payment transactions, this needs to be connected to internet network, these users will be able to make various payments using electronic wallet. Unlike conventional traders who generally when making payments in cash. Electronic wallet has an indirect impact on the community, considering that the means of payment can also be used to pay off various monthly bills such as electricity, water, telephone, etc. with a large enough value. The presence of an electronic wallet can actually accelerate economic growth and financial inclusion in Indonesia, because in this case the use of an electronic wallet that is designed can be used with a variety of different social, cultural, and economic backgrounds and even the business world both online and offline with various good scale is small, medium, or large scale. As an open-platform digital payment infrastructure, electronic wallet has the ability and benefits for every online and offline business, including start-ups. So that all business actors remain competent and highly competitive in the digital age. For example, the types of entrepreneurs both offline and online, can immediately make all transactions digitally, non-cash and non-card. Offline entrepreneurs include traders in traditional markets, drivers of public transportation services, individual shop owners to outlets that have hundreds of branches. Digital payments do not only make it easy for the public to make transactions. Based on the results of interviews with business owners and communities in the city of Tangerang, payments using e-wallets also provide abundant benefits for the business. One of them is speeding up the transaction process, with digital payments will certainly improve the services available to businesses, while the most visible benefit of digital payments is better security because neither the customer nor the business owner needs to provide a lot of money. Not only that, by making payments in the form of electronic wallet transactions will certainly be more accurate. Furthermore, in terms of the community, what attracts users to use e-wallets to conduct their daily transactions is promotional 
offers from e-wallet providers who have built partnerships with many merchants. Promotional offers are usually given in the form of cashback, which amounts to a certain percentage of related transactions or direct discounts. According to a report from Snapcart as much as 57 percent of the total respondents stated that the public or consumers chose a particular store because of the promotion offered when using ewallet, so this clearly shows that Indonesians are still price conscious even though they are categorized as an emerging middle class (Snapcart, 2017). This is also in line with research conducted by Deloitte (2017) that this strategy is suitable for the Indonesian market because most of the population when choosing an item will consider a price. The key to success in a country including Indonesia towards Indonesia 4.0 is inseparable from the level of inclusion of digital technology. With digital technology the use of Indonesian electronic wallets can increase financial inclusion because geographical obstacles can be eliminated with digital capabilities, so that everyone can use electronic wallets. Indonesia's growth will succeed if the use of digital technology not only increases business growth but also in suburbs and villages. So by using an electronic wallet, small, medium and large scale entrepreneurs can develop their products. electronic wallet not only functions to carry out digital payment transactions, but also can send money, store debit and credit cards, and support a variety of financial transactions and lifestyle for users through a variety of features available.

\section{CONCLUSION}

The development of electronic wallet in Indonesia has rapidly had a positive impact both for business people, consumers and society. For business people, electronic wallet helps businesses in bookkeeping and also in terms of payment using it is very practical and makes it easier for businesses to save money directly into the account. For the public, the practicality of payment makes it easy for the public to make payments anywhere without the need to carry cash in the form of cash that is too much both transactions carried out online and offline between the seller and the buyer. Therefore, the presence of an electronic wallet in Indonesia is able to bring geographical factors and the present time is no longer an obstacle or problem in making payment transactions so that Indonesia's growth. There are several suggestions made by the author where although economic growth through digital payments has developed, there are also many people who still have not used and educated about this payment revolution, therefore the government should play a role in planning in the national noncash movement (GNTT) which aims to increase community awareness of the use of electronic money as a payment instrument. If the public is aware of the use of electronic money on digital payments, then businesses are expected to utilize payment systems both physical stores and online stores. No need to worry about security because the government and Bank Indonesia itself has guaranteed and demonstrated its support for the payment system.

\section{REFERENCE}

BCC Research. (2019). Mobile Wallet and Payment Technologies: Global Markets. Retrieved from 
https://www.researchandmarkets.com/reports/4760631/mobile-walletandpaymenttechnologiesglobal?utm_source $=B W \& u t m \_$medium $=$PressRelease\& utm_code $=$ vclvzw\&utm_campaign $=1232603++$ Mobile + Wallet $+\% 26+$ Payment $+\mathrm{T}$ echnologies \%2c+2019\%3a+Worldwide+Market+Analysis+\%26+Outlook+(20172 023)+by+Application \%2c+Mode+of+Payment+and+Region\&utm_exec $=$ jo ca220prd

Capgemini, \& BNP Paribas. (2018). World Payments Report 2018. Retrieved from https://worldpaymentsreport.com/wp-

content/uploads/sites/5/2018/10/World-

Payments-Report-2018.pdf

Deloitte. (2017). Embracing Bricks and Clicks in Indonesia. Retrieved from Deloitte website:https://www2.deloitte.com/content/dam/Deloitte/sg/Documents/consumerbusine ss/sea-cip-deloitte-consumer-insights-embracing-bricks-and-clicks-inindonesia.pdf

Desy Setyowati (2019, Oktober 19) Persaingan Bisnis Dompet Digital Makin Ketat dan Mengerucut. Retrieved from https:// katadata.co.id/berita/2019/10/07/ persaingan-bisnis-dompet-digitalmakin-ketat-dan-mengerucut/1

Jain, M., \& Singla, R. (2017). Digital Wallet: A Handy Solution in the Wake of Demonetisation. Biz and Bytes, 8(1), 188-197.

Shin, D.-H., Jung, J., \& Chang, B.-H. (2012). The Psychology Behind QR Codes:User Experience Perspective. Computers in Human Behavior, 28(4), 14171426.

Siti Hadijah (2018, December 10) Milenial Wajib Tahu Keuntungan Punya Dompet Digital dengan Sistem QR Payment. Retrieved from https://www.cermati.com/artikel/milenial-wajib-tahu-keuntungan-punya-dompetdigital-dengan-sistem-qr-payment.

Snapcart. (2017). Indonesian Consumer Insights: The Growing Price of Maintaining Customer Loyalty. Retrieved from Snapcart website: https:// snapcart.global/indonesian-consumer-insights-customer-loyalty/

Upadhayaya, A. (2012). Electronic Commerce and E-wallet. International Journal of Recent Research and Review, 1, 37-41.

Pachpande, B. R., \& Kamble, A. A. (2018). Study of E-wallet Awareness and Its Usage in Mumbai. Journal of Commerce \& Management Thought, 9(1), 33-45. https:// doi.org/10.5958/0976-478X.2018.00004.6

Peraturan Bank Indonesia Nomor 18/40/PBI/2016 Tentang Penyelenggaraan Pemrosesan Transaksi Pembayaran. 